\title{
MOLECULAR CLONING OF TROPONIN I FROM THE TWO-SPOTTED CRICKET, GRYLLUS BIMACULATUS, AND ITS EXPRESSION PATTERN DURING STARVATION
}

\author{
CLONAGEM MOLECULAR DA TROPONINA I DO GRILO AFRICANO, GRYLLUS \\ BIMACULATUS, E SEU PADRÃO DE EXPRESSÃO DURANTE A INANIÇÃO
}

\author{
Kyoungmin MOON ${ }^{1}$; Kisang KWON²; Bo-Kyung YOO ${ }^{3}$; Younghwa $\mathrm{Ko}^{3}$; Ji-Hye SONG ${ }^{3}$; \\ Nuri LEE ${ }^{3}$; Ji-Young CHOI ${ }^{4}$; O-Yu KWON ${ }^{3}$ \\ 1. Respiratory Department, GangNeung Asan Hospital, Gangneung 25440, Korea; 2. Department of Biomedical Laboratory Science, \\ College of Health \& Welfare, Kyungwoon University, Gumi 39160, Korea; 3. Departments of Medical Science and Anatomy \& Cell \\ Biology, College of Medicine, Chungnam National University, Daejeon 34134, Korea. oykwon@ @nu.ac.kr; 4. Applied Entomology \\ Division, National Academy of Agricultural Science, RDA, Wanju 55365, Korea.
}

\begin{abstract}
There is few information about troponin gene expression by starvation in insect skeletal muscle and digestive tracts. The objective of this study was to perform molecular cloning of troponin I from the two-spotted cricket, Gryllus bimaculatus (GrybiTnI) and determine its expression patterns in three different skeletal muscles and digestive tracts during starvation. GrybiTnI was translated into a protein encoding 198 amino acids with a theoretical isoelectric point of 9.78 and a molecular weight of 23671.46 Da. The GrybiTnI has both the TnC-binding site and actin/TnC-binding site shown in the typical TnI amino acid sequences. Homology analysis revealed that GrybiTnI exhibited high similarity at the amino acid level to those of other insects already reported; 89 77\% identity with those of other insects. Expression of GrybiTnI by starvation did not change in dorsal wing flight muscle and dorsal ventral flight muscle, but showed up-expression in dorsal longitudinal flight muscle. In the digestive tracts, the up-expression of GrybiTnI by starvation was observed only in the hindgut but not in the rest parts including Malpighian tubules. Re-feeding following starvation restored those expressions about the level before starvation in the dorsal longitudinal flight muscle and hindgut. In conclusion, troponin modulates gene expression not only to muscle elements but also to physiological changes such as strains.
\end{abstract}

KEYWORDS: Two-spotted cricket Gryllus bimaculatus. GrybiTnI cDNA. Starvation. Skeletal muscles. Digestive tracts.

\section{INTRODUCTION}

Starvation causes serious consequences for small-bodied insects. It affects their behavior, development, reproduction, and metabolism (BROUGH; DIXON, 1990; KOUAM; MACKAUER, 1992). Sometimes it can lead to death. Insect adapts to starvation through slowing down their metabolism by regulating gene expression and modifying enzyme (protein) function. It has been reported that starvation influences gene expression in various animals including insects (ZHANG et al., 2008). It has been reported that starvation reduces tissue size and cell proliferation in the midgut of American cockroach (Periplaneta americana) (PARK; TAKEDA, 2008). In addition, starvation induces subsidence of midgut muscle layers through apoptosis (PARK et al., 2009). Starved insects such as Colorado potato beetle, Leptinotarsa decemlineata, are susceptible to pathogen infections due to their compromised immune systems (FURLONG; GRODEN, 2003). Allatotropin gene expression in oriental armyworm, Mythimna separata, and expression of different mitochondrial genes in the yellow fever mosquito, Aedes aegypti, under starvation have been reported (GONÇALVES et al., 2009; ZHANG et al., 2008).

Since various digestive enzymes are secreted either continuously from epithelial cells or spontaneously in response to food, digestive tracts of insects may indicate their modes of life associated with food consumption (WEIDLICH et al., 2013). The digestive tract of G. bimaculatus consists of three parts depending on their embryological origins: foregut (esophagus, crop, and proventriculus), midgut (gastric cecum and midgut), and hindgut (ileum and rectum) (WOODRING; LORENZ, 2007). The function of foregut is mainly for food storage and physical breakdown of food. Ingested food does not usually undergo biochemical changes in the crop due to absence of enzyme secretion in this region. The midgut secretes several kinds of enzymes involved in digestion and absorption of nutrients. It has been suggested that the midgut has very active gene expression and regulation. The hindgut functions in electrolyte balance, water reabsorption, and production of urine from Malpighian tubules. It 
regulates osmotic balance of insects (WOODRING, 2017).

The existence of specific isoforms in different striated muscle cells has implications concerning contractile protein structure/function, gene family evolution, development, and physiological gene regulation (BANDMAN, 1992). How sophisticated muscle physiology is regulated by various isoforms in animals is an interesting research subject. However, the precise regulation of muscles in insects that do not have well-developed isoforms are also important to understand the evolution of protein structure/function, evolutionary isoform process, and developmental gene expression pattern. The house cricket, Acheta domesticus, has three different kinds of skeletal muscles based on ventral dissection: dorsal longitudinal flight muscle (DLM), dorsal ventral flight muscles (DVM), and dorsal wing flight muscles (DWM) (OLIVER et al., 2007). In thin filaments of their striated muscles, troponin I (TnI), troponin $\mathrm{T}(\mathrm{TnT})$, and troponin $\mathrm{C}$ (TnC) are three subunits that form the troponin complex against tropomyosin (Tm) (FARAH \& REINACH, 1995). In Drosophila, one TnI and two kinds of $\mathrm{Tm}(\mathrm{Tm} 1$ and $\mathrm{Tm} 2)$ have been reported. The function of Tn-Tm complex of Drosophila is to regulate nuclear divisions and cell polarity (BULLARD; PASTORE, 2011). However, detail functional mechanisms are currently unclear. They merit further studies.

In the present study, we cloned a cDNA encoding a troponin I ( $\underline{\mathrm{TnI}})$ homolog from Gryllus bimaculatus named GrybiTnI. After characterizing GrybiTnI cDNA based on its sequence, we produced a GrybiTnI antibody to determine its expression patterns in three kinds of muscles (DLM, DVM, and DWM) and digestive tracts during starvation by Western blotting. Results from this study might provide novel clues to understand physiological changes during starvation caused by changes in gene expression in various skeletal muscles of insects.

\section{MATERIALS AND METHODS}

\section{Insects}

Fifth-instar larvae of the two-spotted cricket (G. bimaculatus) used in this study were obtained from Rural Development Administration of Korea (Jeonju, South Korea). Adults were reared at 28$30^{\circ} \mathrm{C}$ with humidity of $70 \%$ under a $10 \mathrm{~h} / 14 \mathrm{~h}$ light/dark photoperiod in transparent plastic cylinders (diameter, $9 \mathrm{~cm}$; height, $10 \mathrm{~cm}$ ). These crickets were fed a commercial feed suited for rats and rabbit (1:6) with unlimited water supply.
Crickets with synchronous growth from the fifth instar to adult emergence were selected. Only males were used in the following experiments. Due to cannibalism, each vial contained only a single male cricket. During starvation, crickets were provided free access to water. However, they were not fed for 6 days.

\section{Cloning and characterization of GrybiTnI cDNA}

A cricket was anesthetized by exposure to $\mathrm{CO}_{2}$ gas for dissection. Its body was cut open ventrally from the last abdominal segment to the neck. Each tissue was obtained under virtual microscopy (Nikon Eclipse E600). Total RNA was extracted from each tissue using Trizol reagent (Invitrogen, Carlsbad, CA, USA) and further treated with RNase free DNase-I to remove any potential genomic DNA contamination. Marathon cDNA amplification kit (Clontech, Palo Alto, CA, USA) was then used to construct cDNA library using 1.5 $\mu \mathrm{g}$ of mRNA as template. BLAST search was used for gene identification. PCR was performed using primers designed with Primer3 (http://simgene.com/Primer3) based on Conserved Domain Databases form National Center for Biotechnology Information (NCBI, Bethesda, MD, USA) and Motif Databases (GenomeNet, Institute for Chemical Research, Kyoto University, Japan). The number of PCR cycles was optimized to obtain linear range of amplification. RT-PCR was performed using primers GrybiTnI-F 5'AATGGGATGCTTGAAACGGCG-3' and GrybiTnI-R 5'GCGCCTTCAACTAGGTGATGAC-3' and Taq DNA polymerase. PCR program was: 30 cycles of $94^{\circ} \mathrm{C}$ for $30 \mathrm{~s}, 58^{\circ} \mathrm{C}$ for $30 \mathrm{~s}$, and $72^{\circ} \mathrm{C}$ for $1 \mathrm{~min}$ followed by a final extension step at $72^{\circ} \mathrm{C}$ for 10 min. A single band of GrybiTnI amplicon (382 bp) was detected by RT-PCR. The resulting PCR product was sub-cloned into TOPO TA Cloning plasmid (Invitrogen) and sequenced to confirm its identity. All other chemicals and drugs were purchased from Sigma Chemical (St. Louis, MO, USA). Open reading frame, molecular weight, and theoretical isoelectric point were estimated using bioinformatics tools available at ExPASy server (http://www.expasy.org/). Multiple protein sequence alignment was performed using NCBI server (http://www.ncbi.nlm.nih.gov/).

\section{Antibody preparation and Western blot analysis Anti-GrybiTnI antibody was produced by immunizing rabbits with gel homogenate containing 1 mg of 106- CEGQKWDLEHEVRKRDFEISDLNSQ-130}


peptide of GrybiTnI which was synthesized by Young In Frontier Co., LTD (Seoul, Korea). Antigen peptide was injected into rabbits three times at 2-week intervals. Antiserum was collected one week after the last injection. Each tissue was lysed by RIPA buffer ( $25 \mathrm{mM}$ Tris-HCl, pH 7.6, $150 \mathrm{mM}$ $\mathrm{NaCl}, 1 \% \mathrm{NP}-40,1 \%$ sodium deoxycholate, $0.1 \%$ SDS, $1 \mathrm{mM}$ PMSF) and homogenized using a plastic pestle matching a $1.5 \mathrm{ml}$ Tube (SP Scienceware, Wayne, NJ, USA). To measure total protein concentration, Pierce ${ }^{\circledR}$ BCA Protein Assay Kit (Thermo Scientific, Catalogue number: 23225) was used. Proteins were separated by SDSpolyacrylamide gel electrophoresis and transferred to nitrocellulose membrane. The resulting membrane was incubated with primary antibodies overnight at $4^{\circ} \mathrm{C}$. Blots were developed using an enhanced chemiluminescence Western blotting detection system Kit (Amersham, Sweden). AntiGrybiTnI antibody and anti-beta actin antibody (Abcam, Cambridge, UK) were used as a second antibody in the Western blot analysis, respectively.

\section{RESULTS AND DISCUSSION}

We amplified a cDNA of troponin I (TnI) from the fifth-instar larvae of the two-spotted cricket (Gryllus bimaculatus) (named GrybiTnI). This cDNA was cloned with an RT-PCR approach using Conserved Domain Databases (NCBI, Bethesda, MD, USA) and Motif Databases (GenomeNet, Kyoto, Japan). The amplificed GrybiTnI cDNA was composed of a short 5' untranslated sequence of $132 \mathrm{bp}$, a single open reading frame (ORF) of $351 \mathrm{bp}$, and a $3^{\prime}$ untranslated sequence of 194 bp. Its ORF region began with a start codon at position 133 and terminated with a TAG stop codon at position 729 . It encoded a protein of 198 amino acids. Its predicted molecular mass was $23.67 \mathrm{kDa}$ with a theoretical isoelectric point of 9.78 (Figure 1).

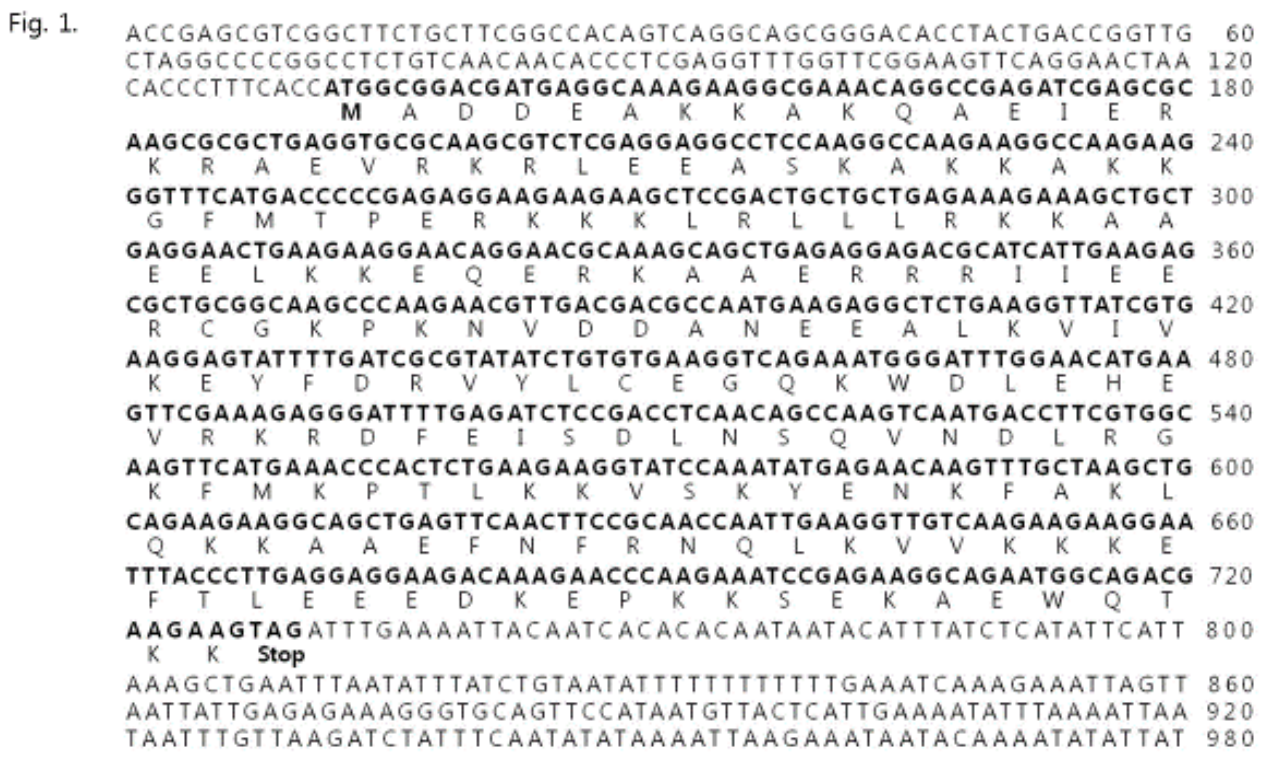

Figure 1. Sequence analysis of GrybiTnI cDNA. Nucleotide sequences of the cDNA encoding GrybiTnI isolated from two-spotted cricket (Gryllus bimaculatus) and its deduced amino acid sequences are shown.

It shared high sequence identities with TnI of other insects, but not with TnI of human (Table 1). GrybiTnI shared $89 \%$ sequence identities with $T$. castaneum, $92 \%$ with A. gambiae, $88 \%$ with $A$. aegypti, $82 \%$ with D. melanogaster, $80 \%$ with $A$. mellifera, and $77 \%$ with B. mori. However, GrybiTnI only shared $21-23 \%$ sequence identifies with Homo sapiens TnI isoforms. 
Table 1. Sequence identities between deduced amino acid sequences of GrybiTnI and those of TnI from other insects and human.

\begin{tabular}{lll}
\hline Species & Accession number & Identity \\
\hline Tribolium castaneum & XP_015834634.1 & $89 \%$ \\
Anopheles gambiae & XP_001688628.1 & $92 \%$ \\
Aedes aegypti & XP_001661102.1 & $88 \%$ \\
Drosophila melanogaster & NP_523398.1 & $82 \%$ \\
Apis melifera & NP_001035346.1 & $80 \%$ \\
Bombyx mori & NP_001037295 & $77 \%$ \\
Homo sapiens (cardiac) & NP_000354.4 & $23 \%$ \\
Homo sapiens (skeletal, fast) & NP_003273.1 & $21 \%$ \\
Homo sapiens(skeletal, slow) & NP_003272.3 & $21 \%$ \\
\hline
\end{tabular}

Multiple sequence alignment was performed for GrybiTnI compared to TnI of other insects (Figure 2). Compared to other regions, both $\mathrm{TnC}$ binding site and actin/TnC-binding site were highly conserved in insects except $B$. mori. Considering that $\mathrm{TnI}$ acts as a calcium dependent molecular switch in skeletal muscle contraction regulation, the conservation of these two regions of TnI in different insect species suggests that TnI might be an indispensable biomolecular for contractionrelaxation in the skeletal muscle of insects.

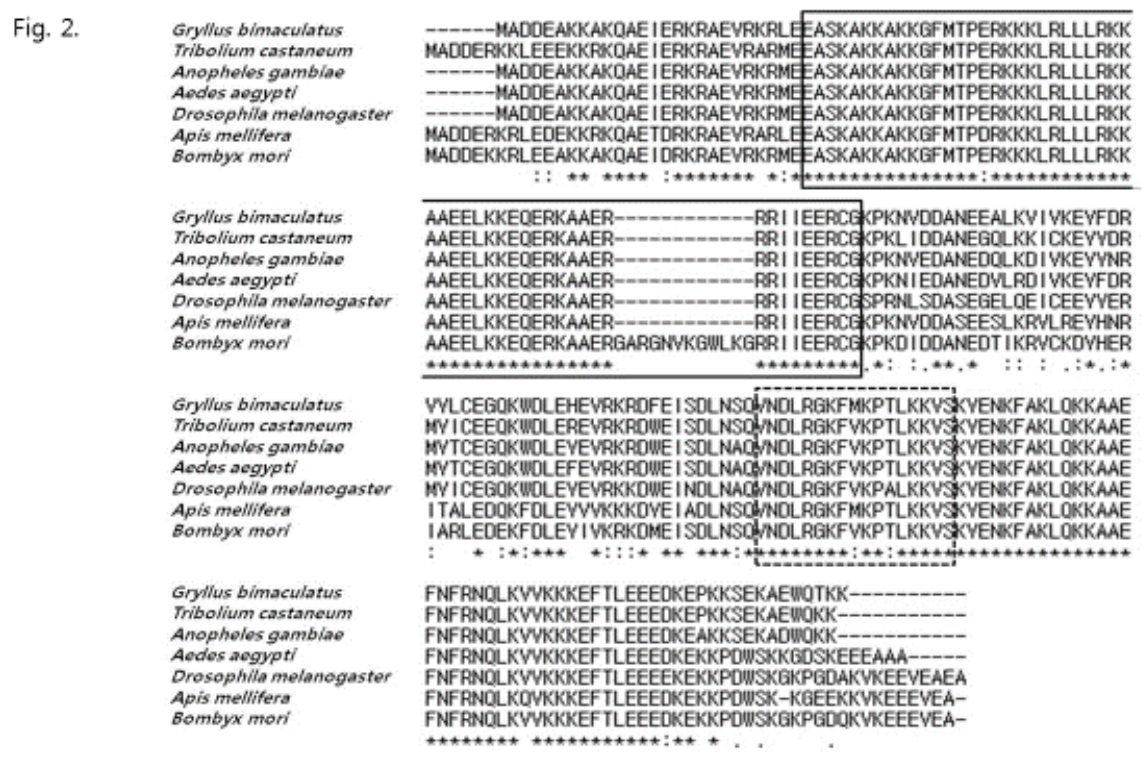

Figure 2. Comparison of amino acid sequences between GrybiTnI and TnI from other insects. TnI sequences from red flour beetle (Tribolium castaneum), African malaria mosquito (Anopheles gambiae), Yellow fever mosquito (Aedes aegypti), Fruit fly (Drosophila melanogaster), Honeybee (Apis mellifera), and Silkworm (Bombyx mori) were used for comparison. Amino acid sequences were obtained from NCBI/GenBank database. Identity and similarity of amino acid residues are indicated by (*) and (:) or (.), respectively. TnC-binding site is shown in closed line-box. Actin/TnC-binding site is indicated by dot-box.

Starvation is one of the most serious problems that an insect experience for survival. To overcome starvation, insects undergo various physiological changes such as behavior, development, reproduction, and metabolism. It is well-known that insects will reduce their metabolic rates during starvation to increase energy stores of glycogen and triglycerides (DE VRIES et al., 2015).
Starvation is known to reduce tissue size and cell proliferation in the midgut of American cockroach (Periplaneta americana) and induce subsidence of midgut muscle layers through apoptosis (PARK; TAKEDA, 2008). In addition, it has been reported that starved Colorado potato beetles (Leptinotarsa decemlineata) are very susceptible to pathogen infections (FURLONG; GRODEN, 2003). In this 
study, we investigated how starvation affected GrybiTnI expression in muscles (DLM, DWM, and DVM) and digestive tracts [foregut (esophagus, crop, and proventriculus), midgut (gastric cecum and midgut) and hindgut (ileum and rectum)] of crickets.

To determine the relative expression level of GrybiTnI in each tissue under normal condition, total proteins of DLM, DWM, DVM, fat body, Malpighian tubules, foregut, midgut, and hindgut were prepared from the G. bimaculatus. As shown in Figure 3A, GrybiTnI expression is about four times higher in DVM compared to that in DLM or DWM, respectively. The GrybiTnI gene is expressed at a high level, lower than that of DVM and higher than that of DLM, in the fat body, however which is almost undetectable in Malpighian tubules.

In digestive tracts, GrybiTnI was expressed more in the hindgut, followed by that in the foregut and midgut. These results suggest that GrybiTnI is expressed at various levels in different tissues under normal breeding conditions.

Next, we determined whether starvation regulated the expression of GrybiTnI in three kinds of skeletal muscles (DLM, DWM, and DVM) (Figure 3B). In this experiment, the starvation period lasted for six days. This period was chosen because six days were needed so that the digestive tract (from esophagus to anus) of starved $G$. bimaculatus completely had no food. In addition, the survival rate of crickets after 6 days of starvation was about $50 \%$. Despite starvation treatment, GrybiTnI expression levels in DWM and DVM were unchanged compared to its expression levels under normal condition. However, the GrybiTnI gene expression has increased about 1.5 times as much in the DLM as in DWM/DVM by starvation.

Although the exact mechanism contributing to this result is currently unclear, this result suggests that muscle physiological changes such as proteolysis often observed in insect muscles during starvation might occur the most in DLM. Next, expression of GrybiTnI in digestive tracts (foregut, midgut, and hindgut) including Malpighian tubules during starvation was determined. Results are shown in Figure 3C. The expression level of GrybiTnI was only increased about 1.5 times in hindgut by starvation treatment, however, no significant changes shown in the foregut, midgut, and Malpighian tubules. Although various enzymes necessary for the digestion of food are constantly secreted in large quantities, there is no change in the expression of GrybiTnI in cells constituting the midgut during starvation. Considering that ileum is the largest member in the hindgut, the expression of GrybiTnI might be increased in cells constituting ileum during starvation. To further determine GrybiTnI expression increase in the ileum during starvation, histological studies and physiological studies involving water reabsorption and electrolyte regulation were performed. As shown in Figure 3C, starvation induced GrybiTnI expression both in DLM and hindgut. We then determined tested whether GrybiTnI expression induced by starvation could return to its original state by re-feeding time. Our results showed that GrybiTnI expression of hindgut was restored to its level observed under fully fed state after re-feeding for one day. However, GrybiTnI expression in DLM needed two days to restore its normal level (Figure 3D). Therefore, the recovery of GrybiTnI expression to its pre-starvation level in hindgut was faster than that in DLM by one day. This might be due to the fact that GrybiTnI in DLM is activated through several pathways whereas GrybiTnI in hindgut can be activated by food there which is directly converted to energy. 
Fig. 3.

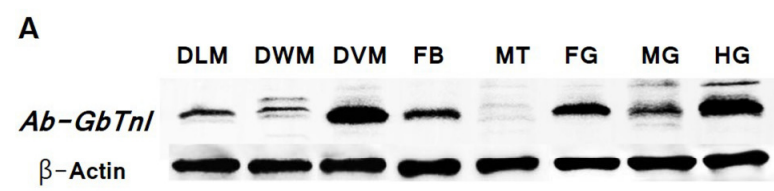

B

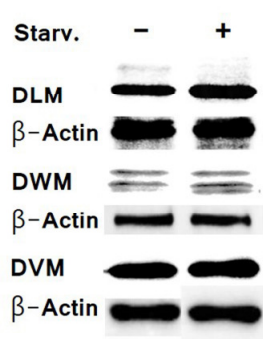

C

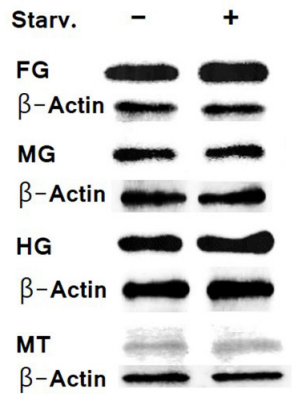

D
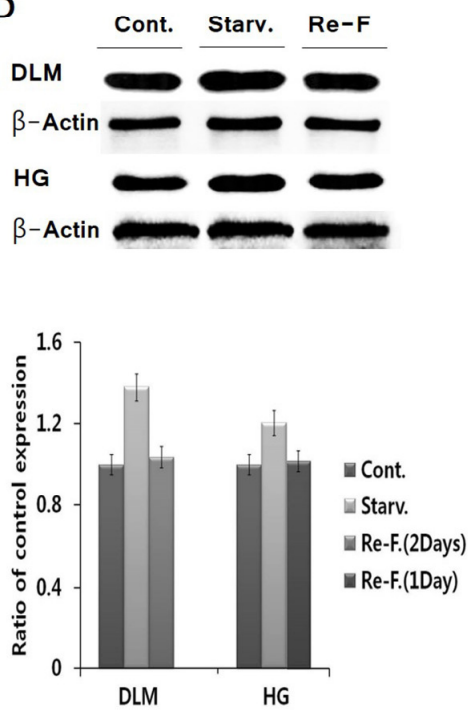

Figure 3. Expression of GrybiTnI in G. bimaculatus under continuous feeding or starvation condition. (A) GrybiTnI expression pattern in various tissues during continuous feeding. DLM, dorsal longitudinal flight muscle; DWM, dorsal wing flight muscle; DVM, dorsal ventral flight muscle; FB, fat body; MT, Malpighian tubules; FG, foregut; MG, midgut; HG, hindgut. (B) Western blot analysis of GrybiTnI expression in muscles under continuous feeding (-) or starvation (+) condition. (C) Western blot analysis of GrybiTnI expression in digestive tracts including MT under continuous feeding (-) or starvation (+) condition. (D) Regulation of GrybiTnI expression by re-feeding in both DLM and HG.

In summary, we isolated a Gryllus bimaculatus troponin I cDNA (GrybiTnI) encoding 198 amino acids with a molecular weight of 23671.46 Da. Its amino acid sequences have both TnC-binding site and actin/TnC-binding site typically found in $\mathrm{TnI}$ of various insect species. GrybiTnI shared relatively high sequence identifies with TnI of other insects. The strongest GrybiTnI expression was found at DVM in muscles and the hindgut in digestive tracts. Starvation induced upregulation of GrybiTnI expression in both DLM and hindgut. Re-feeding following starvation restored its expression to the level before starvation. To the best of our knowledge, this is the first report of the expression of GrybiTnI in skeletal muscle of insects during starvation. The precise mechanism regulating its expression is currently unclear. However, our results might provide novel insights on muscle physiology and insect physiology.

\section{ACKNOWLEDGEMENT}

This study was supported by a grant (PJ010864) from the Agenda program funded by Rural Development Administration, Republic of Korea.

RESUMO: Existe pouca informação sobre a expressão gênica da troponina por inanição no músculo esquelético de insetos e no trato digestório. O objetivo deste estudo foi realizar clonagem molecular da troponina I do grilo africano, Gryllus bimaculatus (GrybiTnI) e determinar seus padrões de expressão em três diferentes músculos esqueléticos e tratos digestivos durante a inanição. GrybiTnI foi traduzido em uma proteína codificando 198 aminoácidos com um ponto isoelétrico teórico de 9,78 e um peso molecular de 23671,46 Da. O GrybiTnI tem o local de ligação a TnC e o local de ligação a actina/TnC mostrado nas sequências de aminoácidos TnI típicas. A análise de homologia revelou que GrybiTnI exibiu alta similaridade no nível de aminoácidos em relação àqueles de outros insetos já relatados; 89 77\% de identidade com os de outros insetos. A expressão de GrybiTnI pela inanição não se alterou no músculo de vôo da asa dorsal e no músculo de vôo ventral dorsal, mas mostrou expressão positiva no músculo de vôo longitudinal dorsal. Nos tratos digestivos, a expressão positiva de GrybiTnI por inanição foi observada apenas no intestino grosso, mas não nas partes de repouso, incluindo os túbulos de Malpighi. A realimentação após a inanição restaurou as expressões aproximadamente ao nível antes da inanição no músculo de vôo longitudinal dorsal e no intestino grosso. Em conclusão, a troponina modula a 
expressão gênica não apenas em elementos musculares, mas também em alterações fisiológicas, como as cepas.

PALAVRAS-CHAVE: Grilo africano. Gryllus bimaculatus. GrybiTnI cDNA. Inanição. Músculos esqueléticos. Tratos Digestivos.

\section{REFERENCES}

BANDMAN, E. Contractile protein isoforms in muscle development. Developmental Biology, v. 154, p. 273-283. 1992. https://doi.org/10.1016/0012-1606(92)90067-Q

BROUGH, C. N.; DIXON, A. F. G. The effects of starvation on development and reproductive potential of apterous virginoparae of vetch aphid, Megoura viciae. Entomologia Experimentalis et Applicate, v. 55, p. 41-45. 1990. https://doi.org/10.1111/j.1570-7458.1990.tb01346.x

BULLARD, B.; PASTORE, A. J. Regulating the contraction of insect flight muscle. Journal of Muscle Research and Cell Motility, v. 32, p. 303-313. 2011. https://doi.org/10.1007/s10974-011-9278-1

DE VRIES, Z. C.; KELLS, S. A.; APPEL, A. G. Effects of starvation and molting on the metabolic rate of the bed bug (Cimex lectularius L.). Physiological and Biochemical Zoology, v. 88, p. 53-65. 2015.

https://doi.org/10.1086/679499

FARAH, C. S.; REINACH, F. C. The troponin complex and regulation of muscle contraction. Federation of American Societies for Experimental Biology Journal, v. 9, p. 755-767. 1995.

https://doi.org/10.1096/fasebj.9.9.7601340

FURLONG, M. J.; GRODEN, E. Starvation induced stress and the susceptibility of the Colorado potato beetle, Leptinotarsa decemlineata, to infection by Beauveria bassiana. Journal of Invertebrate Pathology, v. 83, p. 127-138. 2003. https://doi.org/10.1016/S0022-2011(03)00066-1

GONÇALVES, R. L.; MACHADO, A. C.; PAIVA-SILVA, G. O.; SORGINE, M. H.; MOMOLI, M. M.; OLIVEIRA, J. H.; VANNIER-SANTOS, M. A.; GALINA, A.; OLIVEIRA, P. L.; OLIVEIRA, M. F. Bloodfeeding induces reversible functional changes in flight muscle mitochondria of Aedes aegypti mosquito. Public Library of Science One, v. 16, p. e7854. 2009. https://doi.org/10.1371/journal.pone.0007854

KOUAM, C. K. L.; MACKAUER, M. Influence of starvation on development and reproduction in apterous virginoparae of the pea aphid, acyrthosiphon pisum (harris) (homoptera: aphididae). Canadian Entomologist, v. 124, p. 87-95. 1992. https://doi.org/10.4039/Ent12487-1

OLIVER, R. H.; ALBURY, A. N.; MOUSSEAU, T. A. Programmed cell death in flight muscle histolysis of the house cricket. Journal of Insect Physiology, v. 53, p. 30-39. 2007.

https://doi.org/10.1016/j.jinsphys.2006.09.012

PARK, M. S.; PARK, P.; TAKEDA, M. Starvation induces apoptosis in the midgut nidi of Periplaneta americana: a histochemical and ultrastructural study. Cell and Tissue Research, v. 335, p. 631-638. 2009. https://doi.org/10.1007/s00441-008-0737-y

PARK, M. S.; TAKEDA, M. Starvation suppresses cell proliferation that rebounds after refeeding in the midgut of the American cockroach, Periplaneta americana. Journal of Insect Physiology, v. 54, p. 386-392. 2008. https://doi.org/10.1016/j.jinsphys.2007.10.011

WEIDLICH, S.; MÜLLER, S.; HOFFMANN, K. H.; WOODRING, J. Regulation of amylase, cellulase and chitinase secretion in the digestive tract of the two-spotted field cricket, Gryllus bimaculatus. Archives of Insect Biochemistry and Physiology, v. 83, p. 69-85. 2013. https://doi.org/10.1002/arch.21092 
WOODRING, J. The flow and fate of digestive enzymes in the field cricket, Gryllus bimaculatu. Archives of Insect Biochemistry and Physiology, v. 95, p. e21398. 2017. https://doi.org/10.1002/arch.21398

WOODRING, J.; LORENZ, M. W. Feeding, nutrient flow, and functional gut morphology in the cricket Gryllus bimaculatus. Journal of Morphology, v. 268, p. 815-825. 2007. https://doi.org/10.1002/jmor.10554

ZHANG, L.; LUO, L.; JIANG, X. Starvation influences allatotropin gene expression and juvenile hormone titer in the female adult oriental armyworm, Mythimna separata. Archives of Insect Biochemistry and Physiology, v. 68 , p. 63-70. 2008. https://doi.org/10.1002/arch.20255 